Article

\title{
Surface Layer Protein A Expressed in Clostridioides difficile DJNS06-36 Possesses an Encephalitogenic Mimotope of Myelin Basic Protein
}

\author{
John E. Mindur ${ }^{1,2}$, Sudhir K. Yadav ${ }^{1}$, Naoko Ito ${ }^{1}$, Mitsutoshi Senoh ${ }^{3}$, Haru Kato ${ }^{3}$, Suhayl Dhib-Jalbut ${ }^{1}$ \\ and Kouichi Ito ${ }^{1, *}$
}

Citation: Mindur, J.E.; Yadav, S.K.; Ito, N.; Senoh, M.; Kato, H.; DhibJalbut, S.; Ito, K. Surface Layer Protein A Expressed in Clostridioides difficile DJNS06-36 Possesses an Encephalitogenic Mimotope of Myelin Basic Protein. Microorganisms 2021, 9, 34. https://dx.doi.org/ 10.3390/microorganisms 9010034

Received: 26 November 2020 Accepted: 21 December 2020 Published: 24 December 2020

Publisher's Note: MDPI stays neutral with regard to jurisdictional claims in published maps and institutional affiliations.

Copyright: () 2020 by the authors. Licensee MDPI, Basel, Switzerland. This article is an open access article distributed under the terms and conditions of the Creative Commons Attribution (CC BY) license (https: / / creativecommons.org/ licenses/by/4.0/).
1 Department of Neurology, Rutgers-Robert Wood Johnson Medical School, Piscataway, NJ 08854, USA; jmindur@g.harvard.edu (J.E.M.); yadavsk@rwjms.rutgers.edu (S.K.Y.); itona@rwjms.rutgers.edu (N.I.); jalbutsu@rwjms.rutgers.edu (S.D.-J.)

2 Center for Systems Biology, Massachusetts General Hospital and Harvard Medical School, Boston, MA 02114, USA

3 Department of Bacteriology II, National Institute of Infectious Diseases, Tokyo 208-001, Japan; senoh@nih.go.jp (M.S.); cato@nih.go.jp (H.K.)

* Correspondence: itoko@rwjms.rutgers.edu; Tel.: +1-732-235-5482

\begin{abstract}
Multiple sclerosis (MS) is an inflammatory demyelinating disease of the central nervous system (CNS). Recent studies suggest that migration of Th1 and Th17 cells specific for enteric bacteria from the gut to the CNS may lead to the initiation and/or exacerbation of autoimmune diseases including MS. Human leukocyte antigen (HLA)-DR15 is an MHC class II (MHCII) haplotype highly associated with the development of MS that contains the two HLA-DRB* genes, DRB1*1501 (DR2b) and DRB5*0101 (DR2a). To identify enteric bacteria which harbor antigenic epitopes that activate myelin-specific $\mathrm{T}$ cells and drive CNS inflammation, we screened for enteric bacteria which express cross-reactive epitopes ('mimotopes') of an immunodominant myelin basic protein 89-98 (MBP $89-98$ ) epitope. Based on known MHCII HLA-DR2a amino acid binding motifs and cultivation with splenic T cells isolated from MBP-T cell receptor (TCR)/DR2a transgenic (Tg) mice, we discovered that a certain variant of surface layer protein A (SLPA), which is expressed by a subtype of Clostridioides difficile, contains an amino acid sequence that activates $\mathrm{MBP}_{89-98}$-reactive $\mathrm{T}$ cells. Furthermore, activation of MBP-specific T cells by SLPA upon active immunization induced experimental autoimmune encephalomyelitis (EAE) in MBP-TCR/DR2a Tg mice. This study suggests that a unique strain of C. difficile possesses an encephalitogenic mimotope of MBP that activates autoreactive, myelin-specific T cells.
\end{abstract}

Keywords: Clostridioides difficile; surface layer protein A; multiple sclerosis; myelin basic protein; mimotope

\section{Introduction}

Multiple sclerosis (MS) is an immune-mediated inflammatory and demyelinating disease of the central nervous system (CNS) [1]. The differentiation and migration of myelin-specific Th1 and Th17 cells from the gut tissues into the CNS has been suggested as an initial event in MS pathogenesis. Although myelin-specific T cells are present in healthy individuals, regulatory immune cells suppress their differentiation into encephalitogenic cells. However, infections by microorganisms may sometimes break immune tolerance and potentially favor myelin-specific $\mathrm{T}$ cell escape from immune tolerance mechanisms. Molecular mimicry is one hypothesis that has been proposed as a mechanism to explain how autoreactive $\mathrm{T}$ cells are able to differentiate into pathogenic cells that drive autoimmune disease development [2]. Typically, foreign and self-antigens (or autoantigens) are processed and presented by antigen-presenting cells (APCs) as peptide fragments and CD4 ${ }^{+} \mathrm{T}$ cells recognize these processed peptide sequences, which are comprised of approximately 
10-16 amino acids, by binding to MHC class II (MHCII) molecules via their T cell receptor (TCR). Peptide epitopes comprised of similar amino acids bearing a structural resemblance to autoantigen epitopes, or 'mimotopes', can also bind to specific pockets within MHCII upon antigen processing, and these mimotope:MHCII complexes may activate autoreactive T cells [3-6].

Although the etiology of MS is still unknown, it has been suggested that genetic and environmental elements are mutually involved in the initiation and progression of MS [1]. Among MS-associated genetic elements, the MHCII HLA-DR gene is the most strongly associated element [7]. HLA-DR15, containing the DRB1*1501 (DR2b) and DRB5*0101 (DR2a) genes, is highly associated with MS, suggesting that DR2a- or DR2b-restricted T cells may be involved in MS pathogenesis. Among environmental factors, gut dysbiosis (i.e., an alteration among gut microbial species) has been reported as a major MS-associated factor [8-11]. Studies on gut dysbiosis in animal models of MS suggest the relative expansion of pathogenic microbes reduces the abundance of bacteria that promote Foxp ${ }^{+}$ Treg development (e.g., Clostridium and Prevotella species), therefore increasing the risk of MS [12,13]. Additionally, gut dysbiosis increases intestinal permeability and subsequently induces systemic circulation of pathogen-associated molecular patterns (PAMPs) produced by enteric bacteria, which increases the degree of systemic and CNS inflammation [14].

Recent studies also suggest that pathogenic Th17 cells can migrate into other organs from the gut [13]. Importantly, Th17 cells specific for microbial components can migrate into peripheral lymphoid organs and initiate autoimmunity [15]. Although T cells undergo tolerance to gut bacteria, the expansion of pathogenic intestinal bacteria may break this immune tolerance and induce the development of $\mathrm{T}$ cells specific for enteric bacterial antigens. In turn, gut bacteria-specific $T$ cells may migrate into the blood circulation. Indeed, gut microbiota-specific T cells are detected in the blood of IBD patients [16]. Even in healthy individuals, gut microbiota-reactive T cells can be detected in the blood [17]. Therefore, if T cells specific for enteric bacteria happen to encounter APCs presenting CNS autoantigens and cross-react to these autoantigens, their activation and migration into peripheral lymphoid organs and the CNS are high-risk cellular events for CNS autoimmunity. $\mathrm{MBP}_{89-98}$ is an immunodominant T cell epitope of MBP in HLA-DR15 ${ }^{+}$individuals [18]. We previously showed that DR2a-restricted $\mathrm{MBP}_{89-98}$-specific Th17 cells are highly encephalitogenic in DR2a Tg mice $[19,20]$. In this study, we investigated whether enteric bacteria express mimotopes of $\mathrm{MBP}_{89-98}$. We searched for putative mimotope candidate peptide sequences through the NCBI Microbial Protein Database based on known HLADR2a antigenic binding motifs, and upon screening the 28 putative candidates, found that surface layer protein A (SLPA) expressed in a subset of Clostridioides difficile possesses encephalitogenic mimotope of $\mathrm{MBP}_{89-98}$.

\section{Materials and Methods}

\subsection{Determination of Candidate Bacterial Mimicry Peptide Epitopes for Screening}

Proteins encoding potential $\mathrm{MBP}_{89-98}$ mimotope sequences were determined by searching through Microbial Protein BLAST by convention of the Protein BLAST program (BLASTP) available through NIH NCBI. The explored genomes were limited to microbial species that can colonize humans and mice. Therefore, the search set was narrowed down to genera consisting of Bacteroides (taxid:816), Clostridium (taxid:1485), Fusobacterium (taxid:848), Eubacterium (taxid:1730), Ruminococcus (taxid:1263), Peptococcus (taxid:2740), Peptostreptococcus (taxid:1257), Bifidobacterium (taxid:1678), Escherichia (taxid:561) and Lactobacillus (taxid:1578) [21]. For the listed genera, a total of 41,724,149 sequences were screened. The amino acid queries for candidate mimotopes were designed to share sequence homology with the immunodominant $\mathrm{MBP}_{89-98}$ epitope, particularly for residues 89-98 (FFKNIVTPRT), since these amino acid residues structurally fit into the MHCII HLA-DR2a binding pocket [22] and can establish contact with the 3A6 T cell receptor (TCR) of myelin-reactive $\mathrm{MBP}_{89-98}$-specific T cells $[19,23]$. The candidate mimotope sequences were further selected based on their predicted MHCII binding capacity 
for HLA-DR2a (HLA-DRB5*01:01) using the IEDB Analysis Resource Consensus Tool (http://tools.iedb.org/mhcii/) [24,25]. Candidate mimotope peptides (Peptide 2.0 Inc., Chantilly, VA, USA) were finally screened by $\mathrm{T}$ cell proliferation assays using $\mathrm{MBP}_{89-98^{-}}$ specific $\mathrm{T}$ cells.

\subsection{Isolation and Characterization of Clostridioides difficile}

C. difficile strain DJNS06-36 was identified as PCR ribotype (RT) gc0636. It was isolated from the stool of an 83-year-old woman on 11/24/2005 in Gifu, Japan. She presented to her general practitioner with diarrhea and abdominal cramping and was admitted to hospital. She had taken tosufloxacin for her upper respiratory infection as outpatient treatment. On admission, laboratory testing for toxin in feces was positive, and she was given the diagnosis of Clostridioides difficile infection (CDI) [26].

C. difficile strain JND10-141 was identified as a unique RTcc10141 strain. It was isolated from the stool of an 80-year-old woman who was hospitalized for her meningioma on 3/29/2010 in Chiba, Japan. She suffered from CDI and recurrence during hospitalization. JND10-141 was isolated from the second episode (recurrence).

\subsection{Generation of Recombinant E. coli Expressing MBP, SLPA, or LacZ}

MBP, SLPA, and LacZ cDNA were introduced into the Champion ${ }^{\mathrm{TM}}$ pET Directional TOPO $^{\circledR}$ Expression Kit (Invitrogen, Carlsbad, CA, USA). BL21 Star ${ }^{\mathrm{TM}}$ (DE3) E. coli was transformed with the recombinant vectors, grown, and then their expression was induced by the addition of $1 \mathrm{mM}$ IPTG into growth media according to manufacturer instructions. The recombinant His(6X)-tagged proteins were subsequently purified utilizing the ProBond ${ }^{\mathrm{TM}}$ Purification System (Invitrogen). The eluted protein was concentrated by PES, 3K MWCO (ThermoFisher Scientific, Waltham, MA, USA). Final concentration of protein was measured using the Pierce ${ }^{\mathrm{TM}}$ BCA Protein Assay Kit (ThermoFisher Scientific).

\subsection{Cell Culture, $T$ Cell Proliferation and Flow Cytometry}

To screen for mimotope peptides of $\mathrm{MBP}_{89-98}$, splenocytes isolated from MBP$\mathrm{TCR} / \mathrm{DR} 2 \mathrm{a}, \mathrm{Tg}$ mice were cultured with candidate peptides at $10 \mu \mathrm{g} / \mathrm{mL}$ and cell proliferation was measured by ${ }^{3} \mathrm{H}$ thymidine uptake using a TriLux Liquid Scintillation Counter (Wallac). To measure IL-17A production in response to C. difficile and recombinant E. coli lysates, $\mathrm{MBP}_{89-98}$-specific Th17 cells were generated by cultivation of splenocytes isolated from MBP-TCR/DR2a Tg mice with IL-6, TGF-beta, and IL-23 as previously described [27]. Dendritic cells (DCs) isolated from DR2a Tg mice were stimulated with Pam3CSK4 at 10 $\mathrm{ng} / \mathrm{mL}$ for 2 days. $\mathrm{MBP}_{89-98}$-specific Th17 cells were cultured with the DR2a ${ }^{+} \mathrm{DCs}$ and $C$. difficile $(30 \mu \mathrm{g} / \mathrm{mL})$ or recombinant E. coli $(60 \mu \mathrm{g} / \mathrm{mL})$ lysates. C. difficile strains DJNS06-36 and JND10-141 recovered from patients who suffered from $C$. difficile infection were used as described above. Cell lysates were prepared by sonication of bacterial suspensions in PBS. To measure the response to SLPA, memory T cells were isolated from MBP-TCR/DR2a Tg mice with memory $\mathrm{T}$ cell isolation microbeads (Miltenyi Biotec, Auburn, CA, USA) and then cultured with DR2a $\mathrm{a}^{+}$DCs and SLPA at $70 \mu \mathrm{g} / \mathrm{mL}$ in the presence or absence of antiHLA-DR monoclonal antibody $(\mathrm{mAb})(10 \mu \mathrm{g} / \mathrm{mL})$. Production of IL-17A was measured by ELISA (BioLegend, San Diego, CA, USA). To examine the expression of IL-17A, GM-CSF, and IFN- $\gamma$ in the brain and spinal cord, CNS cell infiltrates were purified with a 30/70\% percoll-density gradient after digestion of the homogenized brain and spinal cord with Neural Tissue Dissociation kit (Miltenyi Biotec, Auburn, CA, USA). The isolated CNS cells were cultured with $\mathrm{MBP}_{89-98}$ at $10 \mu \mathrm{g} / \mathrm{mL}$ for $5 \mathrm{~h}$ in the presence of brefeldin A $(10 \mu \mathrm{g} / \mathrm{mL})$ and then stained with anti-CD4, -CD3, -IL-17A, -GM-CSF, and -IFN- $\gamma$ mAbs. Anti-CD4, -IFN- $\gamma$, -IL-17A, and -GM-CSF mAbs were all purchased from eBioscience and mAbs against human 3A6 TCR V 35.1 were purchased from Beckman Coulter. Flow cytometry analysis was performed on a Gallios flow cytometer and analyzed by Kaluza Software (Beckman Coulter, Brea, CA, USA). 


\subsection{Mice and EAE Induction of Experimental Autoimmune Encephalomyelitis (EAE)}

MBP-TCR/DR2a Tg mice were immunized s.c. with $200 \mu \mathrm{g}$ of SLPA in Complete Freund's Adjuvant (CFA) (Difco Laboratories, Detroit, MI, USA) on day 0 and 200 ng of pertussis toxin (List Biologicals, St. Louis, MO, USA) was administered i.p. on days 0 and 2 for the induction of EAE. Animals were weighed and monitored daily; clinical signs were assessed according to the following scale: 0 : no disease; 1 : limp tail; 2: mild hindlimb paresis; 2.5: severe hindlimb paresis; 3 : single hindlimb paralysis; 3.5 : complete hindlimb paralysis; 4 : hindlimb paralysis and forelimb paresis; and 5: no mobility/moribund. All experiments were carried out in compliance with the Guide for the Care and Use of Laboratory Animal Resources and approved by the Rutgers-Robert Wood Johnson Medical School Institutional Animal Care and Use Committee.

\section{Results}

3.1. Screening of Gut Microbes for MBP $89-98$ Mimotope Peptides

MBP is a CNS autoantigen in MS and $\mathrm{MBP}_{89-98}$ is one of the encephalitogenic epitopes of MBP that can be recognized by myelin-reactive T cells in the context of MHCII HLADR2a antigen presentation. HLA-DR2a is associated with MS and HLA-DR2a-restricted $\mathrm{MBP}_{89-98} \mathrm{~T}$ cells can be isolated from MS patients [28]. Therefore, we investigated whether microbial proteins derived from intestinal microbes can act as mimotopes to activate $\mathrm{MBP}_{89-98}$-specific T cells. We first screened for potential mimotopes of $\mathrm{MBP}_{89-98}$ amongst enteric microbial proteins through the NCBI Microbial Protein Database based on the amino acids of $\mathrm{MBP}_{89-98}$ that act as MHCII HLA-DR2a antigenic binding motifs [29]. We subsequently found 28 microbial candidates that expressed potential $\mathrm{MBP}_{89-98}$ mimotopes (Table 1). Next, we examined which of the identified enteric bacterial protein(s) could stimulate $\mathrm{MBP}_{89-98}$ reactive $\mathrm{T}$ cells. We utilized splenocytes isolated from humanized transgenic mice that express an $\mathrm{MBP}_{89-98}$-specific human TCR and HLA-DR2a, and are deficient in expression of the endogenous mouse MHCII (I-E and I-A) [19,20]. We generated synthetic decapeptides for each candidate mimotope and screened for cellular proliferation upon culturing the MBP-TCR/DR2a Tg splenocytes with candidate mimotope peptides. $\mathrm{T}$ cell proliferation as assessed by thymidine uptake revealed that synthetic $C$. difficile DJNS06-36 surface layer protein A (SLPA) peptide strongly induced the proliferation of $\mathrm{MBP}_{89-98}$-specific T cells (Figure 1A).

\subsection{Diversity amongst the SLPA Mimotopes in C. difficile Strains}

Notably, SLPA is an adhesion protein expressed by C. difficile that mediates binding and adherence to extracellular matrix proteins and gastrointestinal tissues [30-32]. It is composed of a conserved high-molecular-weight subunit and low-molecular-weight subunit, the latter of which is diverse among C. difficile strains [33-36]. As shown in Figure 1B, the DNA sequence of SLPA is different between C. difficile DJNS06-36 and C. difficile JND10-141. As a result, the amino acid sequence of the SLPA mimicry epitope is different (Table 2). While the $C$. difficile DJNS06-36 genome encodes for the SLPA $180-189$ peptide (GFKLTVTPKS) according to NCBI Microbial Protein Database, the $C$. difficile JND10-141 genome encodes for SLPA $185-194$ peptide (GYKLTITPKT). To test whether the proliferative response is restricted to synthetic C. difficile DJNS06-36 SLPA $180-189$ peptide, we evaluated cellular proliferation in response to both of the SLPA peptide epitopes. Indeed, $\mathrm{MBP}_{89-98}$-specific $\mathrm{T}$ cells proliferated in response to synthetic $C$. difficile DJNS06-36 SLPA $_{180-189}$ peptide; however, synthetic $C$. difficile JND10-141 SLPA $185-194$ did not trigger a proliferative response (Figure 1C). This data indicates that the HLA-DR2a-restricted myelinreactive T cell response is specific to SLPA expressed in a certain strain of $C$. difficile. 
Table 1. Candidate peptide mimotopes of gut microbes.

\begin{tabular}{|c|c|c|c|c|c|c|c|c|c|c|c|c|}
\hline \multirow{2}{*}{$\begin{array}{c}\text { Organism } \\
\text { Anaerostipes hadrus }\end{array}$} & \multirow[t]{2}{*}{ Name of Gene Encoding Candidate Mimotope } & \multicolumn{10}{|c|}{ Peptide Sequence } & \multirow{2}{*}{$\begin{array}{c}\begin{array}{c}\text { NCBI Protein } \\
\text { Accession }\end{array} \\
\text { ZP_19295054.1 }\end{array}$} \\
\hline & & $\mathrm{D}$ & $\mathrm{F}$ & $\mathrm{K}$ & $\mathrm{L}$ & I & $\mathrm{V}$ & $\mathrm{I}$ & $\mathrm{P}$ & $\mathrm{K}$ & $\mathrm{L}$ & \\
\hline Bacillus cereus & $\operatorname{Ger}(X) C$ family germination protein & $\mathrm{R}$ & $\mathrm{Y}$ & $\mathrm{K}$ & $\mathrm{L}$ & $\mathrm{T}$ & $\mathrm{I}$ & $\mathrm{T}$ & $\mathrm{P}$ & $\mathrm{K}$ & $\mathrm{E}$ & ZP_-17590229 \\
\hline Clostridium botulinum & Putative histidine kinase & $\mathrm{F}$ & $\mathrm{Y}$ & $\mathrm{K}$ & $\mathrm{L}$ & $\mathrm{V}$ & $\mathrm{L}$ & $\mathrm{S}$ & K & $\mathrm{R}$ & $\mathrm{N}$ & YP_004385843.1 \\
\hline Clostridium butyricum & Integral membrane protein domain protein & A & $\mathrm{F}$ & $\mathrm{K}$ & $\mathrm{L}$ & $\mathrm{L}$ & K & $\mathrm{T}$ & K & $\mathrm{K}$ & G & ZP_02949557 \\
\hline Clostridium difficile & Biotin/lipoate A/B protein ligase family protein & $\mathrm{L}$ & $\mathrm{F}$ & $\mathrm{K}$ & $\mathrm{L}$ & $\mathrm{I}$ & K & $\mathrm{T}$ & $\mathrm{K}$ & $\mathrm{T}$ & $\mathrm{P}$ & $\mathrm{ZP} \_17070733$ \\
\hline Clostridium difficile & Surface layer protein A & G & $\mathrm{F}$ & $\mathrm{K}$ & $\mathrm{L}$ & $\mathrm{T}$ & $\mathrm{V}$ & $\mathrm{T}$ & $\mathrm{P}$ & $\mathrm{K}$ & S & BAF02835 \\
\hline Campylobacter rectus & Isoleucyl-tRNA synthetase & $\mathrm{K}$ & $\mathrm{F}$ & $\mathrm{K}$ & $\mathrm{L}$ & $\mathrm{V}$ & $\mathrm{L}$ & S & $\mathrm{T}$ & $\mathrm{R}$ & $\mathrm{H}$ & ZP_03610955.1 \\
\hline Campylobacter sp. FOBRC14 & tRNA pseudouridine(38-40) synthase & $\mathrm{F}$ & G & $\mathrm{K}$ & $\mathrm{L}$ & $\mathrm{V}$ & $\mathrm{L}$ & S & S & $\mathrm{R}$ & $\mathrm{T}$ & ZP_10843097.1 \\
\hline Eubacterium cylindroides & Glycosyltransferases involved in cell wall biogenesis & $\mathrm{F}$ & $\mathrm{Y}$ & $\mathrm{K}$ & $\mathrm{L}$ & $\mathrm{I}$ & K & $\mathrm{T}$ & K & $\mathrm{K}$ & A & CBK88797.1 \\
\hline Fusobacterium nucleatum & Integrase/recombinase & $\mathrm{F}$ & $\mathrm{F}$ & $\mathrm{K}$ & $\mathrm{L}$ & $\mathrm{I}$ & Q & $\mathrm{T}$ & K & $\mathrm{S}$ & G & ZP_06750855.1 \\
\hline Helicobacter canadensis & Glutathionylspermidine synthase & $\mathrm{F}$ & $\mathrm{F}$ & $\mathrm{K}$ & $\mathrm{N}$ & $\mathrm{M}$ & $\hat{\mathrm{V}}$ & $\mathrm{I}$ & $\mathrm{L}$ & $\mathrm{K}$ & $\mathrm{F}$ & ZP_04870684.1 \\
\hline Helicobacter pullorum & Glutathionylspermidine synthase & W & $\mathrm{F}$ & $\mathrm{K}$ & $\mathrm{L}$ & I & $\mathrm{P}$ & $\mathrm{W}$ & $\mathrm{E}$ & $\mathrm{S}$ & $\mathrm{I}$ & WP_065826614 \\
\hline Lactobacillus crispatus & Transporter, major facilitator family & $\mathrm{V}$ & $\mathrm{F}$ & $\mathrm{K}$ & $\mathrm{N}$ & $\mathrm{I}$ & K & $\mathrm{T}$ & $\mathrm{R}$ & $\mathrm{T}$ & K & ZP_06627878.1 \\
\hline Lactobacillus crispatus & Transporter, major facilitator family & Y & $\mathrm{Y}$ & $\mathrm{K}$ & $\mathrm{P}$ & $\mathrm{V}$ & $\mathrm{T}$ & $\mathrm{P}$ & K & $\mathrm{K}$ & $\mathrm{T}$ & ZP_06627878.1 \\
\hline Lactobacillus versmoldensis & HNH endonuclease & $\mathrm{D}$ & $\mathrm{Y}$ & $\mathrm{K}$ & $\mathrm{L}$ & $\mathrm{I}$ & K & $\mathrm{T}$ & $\mathrm{K}$ & $\mathrm{K}$ & $\mathrm{G}$ & WP_040521112 \\
\hline Methanobacterium paludis & MtaA/CmuA family methyltransferase & $\mathrm{Q}$ & $\mathrm{F}$ & $\mathrm{K}$ & $\mathrm{S}$ & I & $\mathrm{V}$ & K & $\mathrm{P}$ & $\mathrm{R}$ & $\mathrm{L}$ & WP_013825607 \\
\hline Methanobacterium paludis & Thioesterase & $\mathrm{M}$ & $\mathrm{F}$ & $\mathrm{K}$ & $\mathrm{T}$ & $\mathrm{V}$ & $\mathrm{V}$ & $\mathrm{T}$ & $\mathrm{P}$ & $\mathrm{R}$ & $\mathrm{F}$ & WP_013825042 \\
\hline Methanobrevibacter smithii & DEXX-box ATPase & M & $\mathrm{F}$ & $\mathrm{K}$ & $\mathrm{R}$ & $\mathrm{V}$ & $\mathrm{V}$ & $\mathrm{T}$ & $\mathrm{P}$ & $\mathrm{L}$ & $\mathrm{N}$ & WP_004032273 \\
\hline Methanobrevibacter smithii & Thioesterase & $\mathrm{M}$ & $\mathrm{F}$ & $\mathrm{R}$ & $\mathrm{T}$ & $\mathrm{I}$ & $\mathrm{V}$ & $\mathrm{T}$ & $\mathrm{P}$ & $\mathrm{K}$ & $\mathrm{F}$ & WP_011953703 \\
\hline Peptoniphilus duerdenii & Transcriptional regulator & $\mathrm{N}$ & $\mathrm{F}$ & $\mathrm{K}$ & $\mathrm{L}$ & $\mathrm{V}$ & $\mathrm{K}$ & $\mathrm{T}$ & $\mathrm{K}$ & $\mathrm{K}$ & A & WP_008901584 \\
\hline Prevotella stercorea & Chain length determinant protein & $\mathrm{V}$ & $\mathrm{F}$ & $\mathrm{K}$ & $\mathrm{L}$ & $\mathrm{L}$ & $\mathrm{K}$ & $\mathrm{T}$ & $\mathrm{K}$ & $\mathrm{K}$ & $\mathrm{K}$ & CDE30894 \\
\hline Phascolarctobacterium succinatutens & DNA topoisomerase I & $\mathrm{A}$ & $\mathrm{K}$ & $\mathrm{K}$ & $\mathrm{T}$ & $\mathrm{I}$ & $\mathrm{V}$ & $\mathrm{T}$ & $\mathrm{K}$ & $\mathrm{K}$ & $\mathrm{T}$ & ZP_08075451.1 \\
\hline Prevotella veroralis & Glycine cleavage system $\mathrm{T}$ protein & G & $\mathrm{Y}$ & $\mathrm{R}$ & $\mathrm{L}$ & $\mathrm{I}$ & $\mathrm{S}$ & $\mathrm{T}$ & $\mathrm{P}$ & K & $\mathrm{S}$ & ZP_05856218 \\
\hline Roseburia intestinalis & Lysine-tRNA ligase & $\mathrm{F}$ & K & $\mathrm{K}$ & $\mathrm{N}$ & I & $\mathrm{V}$ & $\mathrm{T}$ & K & $\mathrm{T}$ & $\mathrm{Y}$ & ZP_04745032.1 \\
\hline Ruminococcus torques & Guanine deaminase & K & $\mathrm{Y}$ & $\mathrm{K}$ & $\mathrm{N}$ & $\mathrm{T}$ & $\mathrm{L}$ & $\mathrm{P}$ & $\mathrm{I}$ & $\mathrm{L}$ & $\mathrm{T}$ & CUN31532 \\
\hline Homo sapiens & Myelin basic protein/Golli-Myelin basic protein & $\mathrm{F}$ & $\mathrm{F}$ & $\mathrm{K}$ & $\mathrm{N}$ & $\mathrm{I}$ & $\mathrm{V}$ & $\mathrm{T}$ & $\mathrm{P}$ & $\mathrm{R}$ & $\mathrm{T}$ & NP_001020272 \\
\hline Mus musculus & Myelin basic protein/Golli-Myelin basic protein & $\mathrm{F}$ & $\mathrm{F}$ & $\mathrm{K}$ & $\mathrm{N}$ & $\mathrm{I}$ & $\mathrm{V}$ & $\mathrm{T}$ & $\mathrm{P}$ & $\mathrm{R}$ & $\mathrm{T}$ & NP_034907 \\
\hline
\end{tabular}


A

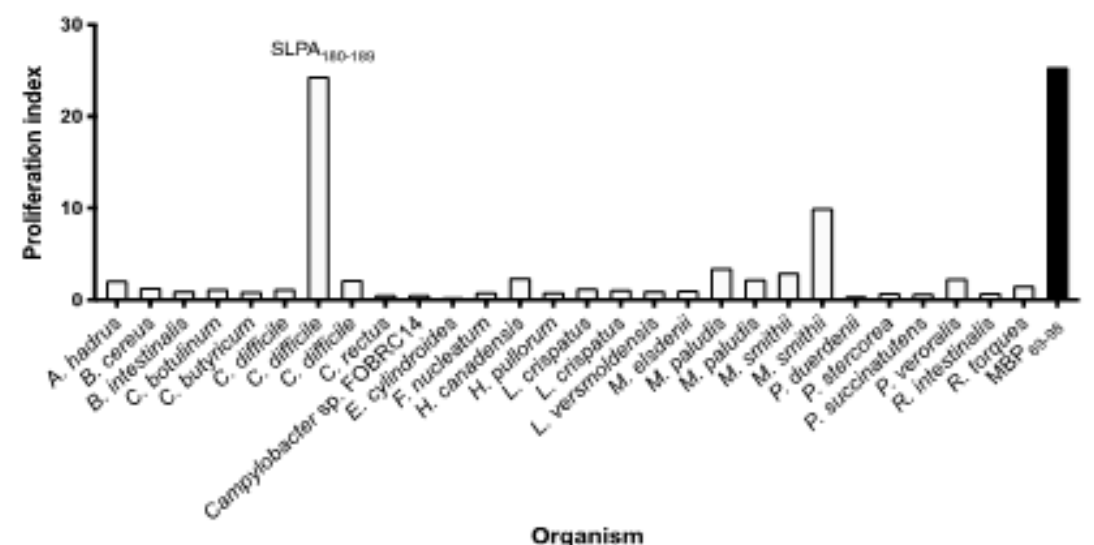

B

Epitope

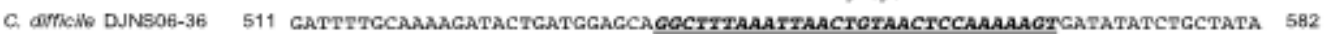
||| ||| | |||| | ||| | || | ||| | ||| |||||||||||| ||| || ||||

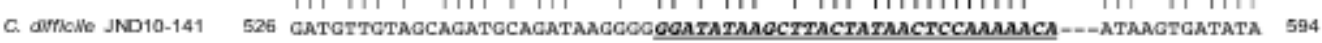

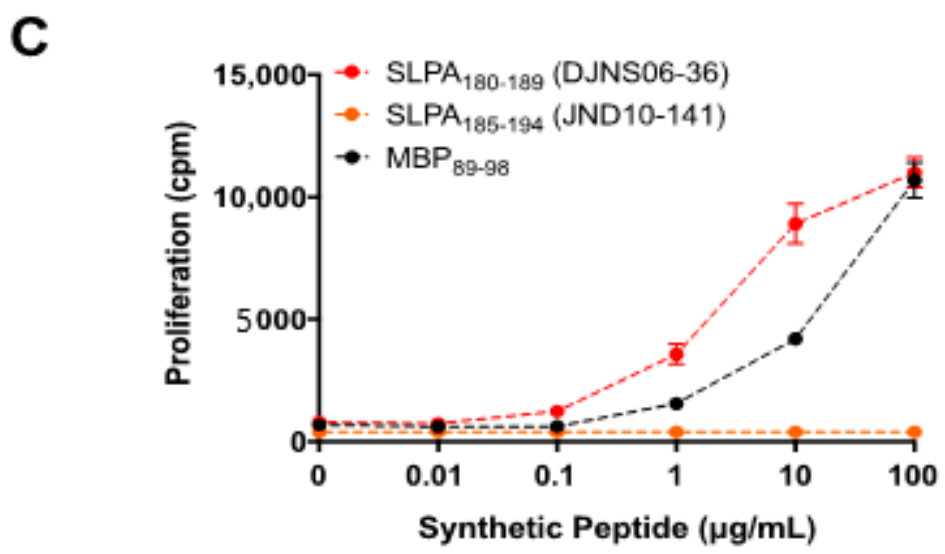

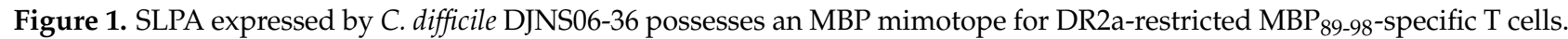
(A) Proliferation of DR2a-restricted MBP-specific Tg T cells in response to synthetic enteric bacteria peptide sequences. Mean of two experiments is presented. (B) Difference in DNA sequence for the MBP mimotope between C. difficile DJNS06-36 and C. difficile JND10-141. (C) Synthetic C. difficile DJNS06-36 SLPA $180-189$ peptide mimotope of MBP $_{89-98}$ for proliferation of DR2a-restricted MBP-specific T cells in comparison to $\mathrm{MBP}_{89-98}$ and synthetic C. difficile JND10-141 SLPA $185-194$ peptide. Data from one representative experiment of three independent experiments is presented.

Table 2. Peptide sequences of SLPA and MBP epitopes.

\begin{tabular}{ccccccccccccccc}
\hline Organisms & \multicolumn{3}{c}{ Peptide } & \multicolumn{4}{c}{} & & & \multicolumn{3}{c}{ Peptide Sequence } & \multicolumn{2}{c}{$\begin{array}{c}\text { NCBI Protein } \\
\text { Accession }\end{array}$} \\
\hline C. difficile DJNS 06-36 & SLPA $_{180-189}$ & G & F & K & L & T & V & T & P & K & S & BAF02835.1 \\
C. difficile JND 10-141 & SLPA $_{185-194}$ & G & Y & K & L & T & I & T & P & K & T & BAM66401.1 \\
Homo sapiens & MBP $_{89-98}$ & F & F & K & N & I & V & T & P & R & T & CAG46717.1 \\
Mus musculus & MBP $_{87-96}$ & F & F & K & N & I & V & T & P & R & T & NP_034907 \\
\hline
\end{tabular}

\subsection{The SLPA Mimotope Can Be Processed and Presented to MBP $89-98$-Specific T Cells}

Although the potent $\mathrm{SLPA}_{180-189}$ mimotope peptide could effectively trigger $\mathrm{MBP}_{89-98^{-}}$ specific $\mathrm{T}$ cell proliferation, it remained unclear whether the entire mimotope could be efficiently processed and presented by MHCII HLA-DR2a on antigen-presenting cells (APCs) following uptake of bacteria containing the SLPA $180-189$ epitope. Thus, we next 
assessed whether co-culture of bacteria encoding the SLPA $_{180-189}$ epitope with HLA-DR2a ${ }^{+}$ $\mathrm{CD}_{11 \mathrm{c}^{+}}$dendritic cells (DCs) could trigger the activation of $\mathrm{MBP}_{89-98^{-}}$-specific $\mathrm{T}$ cells and their subsequent production of pro-inflammatory mediators.

First, we generated Escherichia coli expressing the $\mathrm{MBP}_{89-98}$ epitope (positive control) or an unrelated LacZ sequence (negative control) by transformation of $E$. coli with MBP or LacZ genes, respectively. $\mathrm{MBP}_{89-98}$-specific Th17 cells were generated by cultivation of splenocytes isolated from MBP-TCR/DR2a Tg mice with IL-6, TGF-beta, and IL-23. To confirm that IL-17A can be produced by myelin-specific T cell upon cultivation of

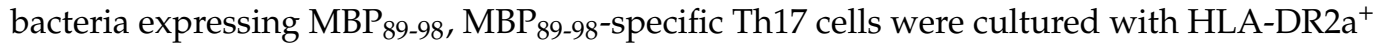

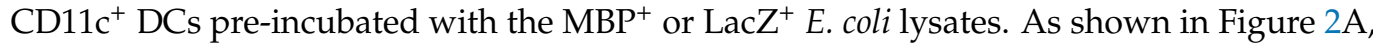
production of IL-17A was detected when $\mathrm{MBP}_{89-98}$-specific $\mathrm{T}$ cells were co-cultured with DCs exposed to $\mathrm{MBP}^{+}$E. coli but not to LacZ ${ }^{+}$E. coli, indicating that IL-17A can be produced in response to the $\mathrm{MBP}_{89-98}$ epitope following antigen processing of $\mathrm{MBP}$ in this in vitro system. Next, we examined whether C. difficile DJNS06-36 SLPA $180-189$ can be processed and presented to $\mathrm{MBP}_{89-98}$ specific Th17 cells. Notably, cultivation of $\mathrm{MBP}_{89-98}$-specific Th17 cells with HLA-DR2a+ ${ }^{+}$D11 ${ }^{+}$DCs exposed to $C$. difficile DJNS06-36 could induce the production of IL-17A (Figure $2 \mathrm{~B}$ ). On the other hand, $\mathrm{MBP}_{89-98}$-specific $\mathrm{T}$ cells could not produce IL-17A when co-cultured with HLA-DR2a ${ }^{+}$CD11c ${ }^{+}$DCs exposed to $C$. difficile JND10-141, likely because this strain lacks the potent $\mathrm{MBP}_{89-98}$ mimotope.

A

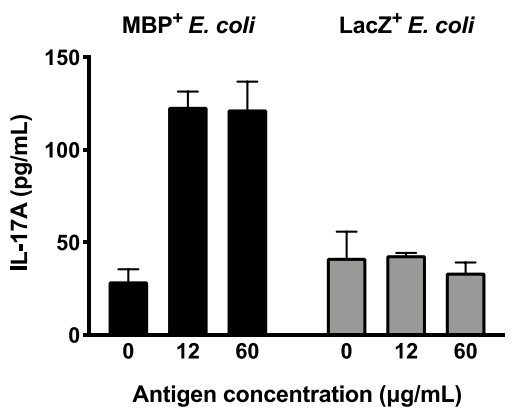

B

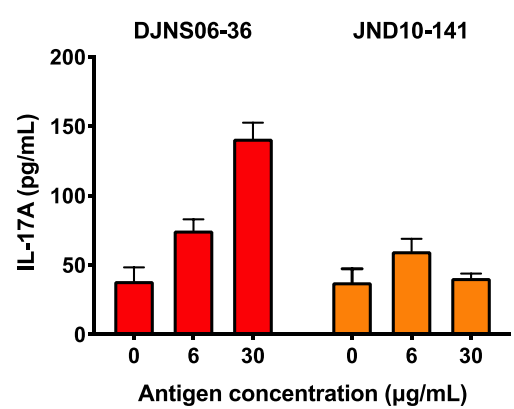

Figure 2. Production of IL-17A in MBP-specific Th17 cells in response to C. difficile DJNS06-36. MBP-specific Th17 cells were cultured with DR2a ${ }^{+}$DCs pulsed with cell extract of either (A) $\mathrm{MBP}^{+}$ E. coli and LacZ ${ }^{+}$E.coli or (B) C. difficile DJNS06-36 and C. difficile JND10-141, and the production of IL-17A was examined. Data from one representative experiment of two independent experiments are presented.

SLPA consists of low- and high-molecular-weight S-layer protein A (LMW-SLPA and HMW-SLPA). Since the $\mathrm{MBP}_{89-98}$ mimotope is found in the genetic sequence that encodes for LMW-SLPA, E. coli was transformed with LMW-SLPA DNA isolated from C. difficile DJNS06-36, and LMW-SLPA was subsequently purified from the LMW-SLPA ${ }^{+}$ E. coli (Figure 3A). To confirm that LMW-SLPA derived from C. difficile DJNS06-36 can be processed and presented to $\mathrm{MBP}_{89-98}$-specific $\mathrm{T}$ cells by HLA-DR2a, the purified LMWSLPA was cultured with HLA-DR2a ${ }^{+}$CD11c ${ }^{+}$DCs and $\mathrm{MBP}_{89-98}$-specific $\mathrm{T}$ cells in the presence of HLA-DR monoclonal antibody $(\mathrm{mAb})$ or isotype control IgG. As shown in Figure 3B, IL-17A production in response to LMW-SLPA was blocked by anti-HLA-DR $\mathrm{mAb}$ but not by isotype control IgG, suggesting that LMW-SLPA can be processed and presented to DR2A-restricted $\mathrm{MBP}_{89-98}$-specific T cells.

\subsection{Induction of EAE in MBP-TCR/DR2a Tg Mice upon Immunization with Purified SLPA}

Since $\mathrm{MBP}_{89-98}$ is one of the encephalitogenic epitopes in MBP, we next assessed whether C. difficile DJNS06-36 LMW-SLPA is an encephalitogenic protein in MBP-TCR/DR2a $\mathrm{Tg}$ mice upon active immunization. We thus induced EAE by immunizing MBP-TCR/DR2a 
Tg mice with the purified LMW-SLPA and monitored the mice for clinical signs of EAE. As expected, we observed the induction of EAE upon immunization with LMW-SLPA/CFA, including the infiltration of $\mathrm{MBP}_{89-98}$-specific Th1 $\left(\mathrm{IFN}-\gamma^{+}\right)$, Th17 $\left(\mathrm{IL}-17 \mathrm{~A}^{+}\right)$, and ThGM $\left(\mathrm{GM}^{-\mathrm{CSF}^{+}}\right.$) cells in the CNS (Figure 4). Therefore, C. difficile DJNS06-36 SLPA can trigger EAE in mice harboring myelin-reactive, $\mathrm{MBP}_{89-98}$-specific $\mathrm{T}$ cells. This data suggests that infection with $C$. difficile DJNS06-36 may increase the risk of CNS autoimmunity in HLA-DR2 $\mathrm{a}^{+}$individuals.

A

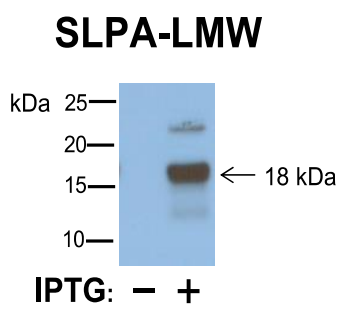

B

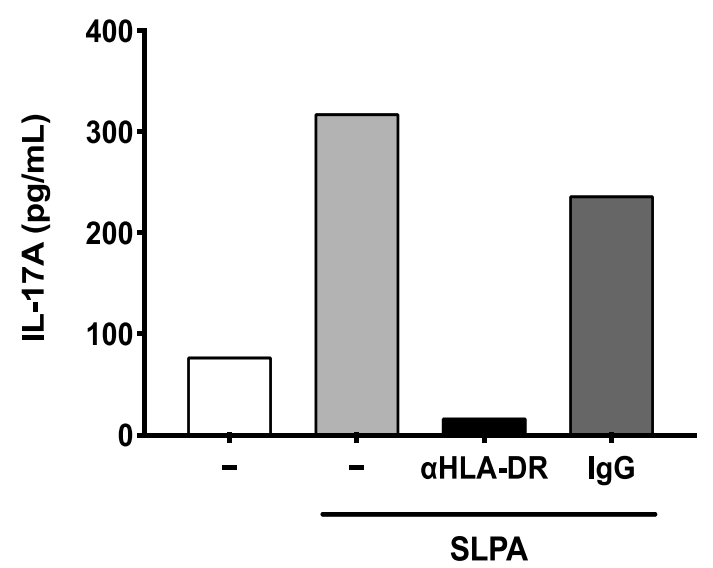

Figure 3. SLPA produced by C. difficile DJNS06-36 can be processed and presented to DR2a-restricted $\mathrm{MBP}_{89-98}$-specific T cells. (A) Purification of LMW-SLPA from BL21 Star ${ }^{\mathrm{TM}}$ (DE3) E. coli that expresses LMW-SLPA DNA isolated from C. difficile DJNS06-36. His(6X)-tagged LMW-SLPA protein was induced by IPTG. (B) Memory T cells isolated from MBP-TCR/DR2a $\mathrm{Tg}$ mice were cultured with the purified LMW-SLPA in the presence of anti-HLA-DR mAb or isotype control IgG. IL-17A production in response to LMW-SLPA in the context of DR2a was examined. Data from one representative experiment of two independent experiments is presented.

A

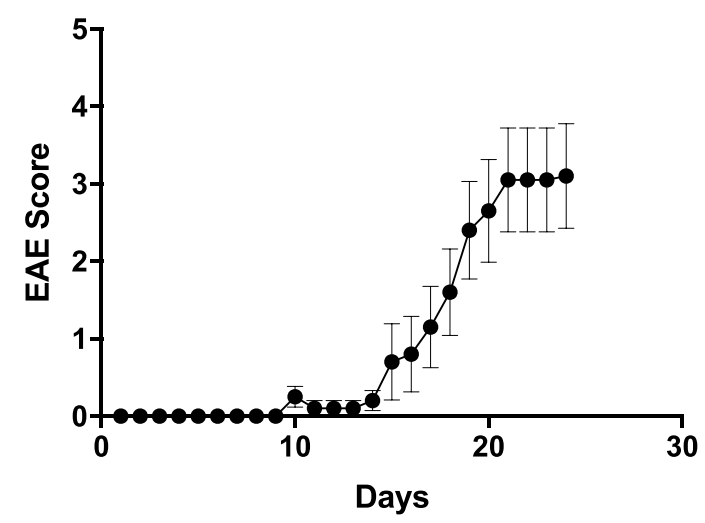

B
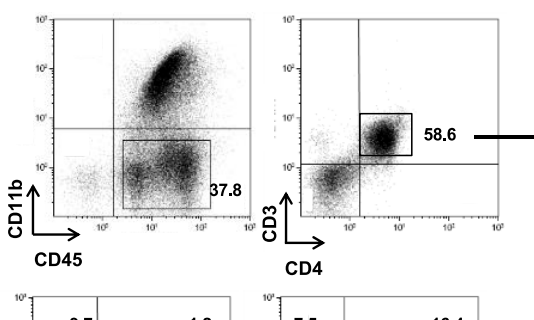

Stimulation with MBP89-98
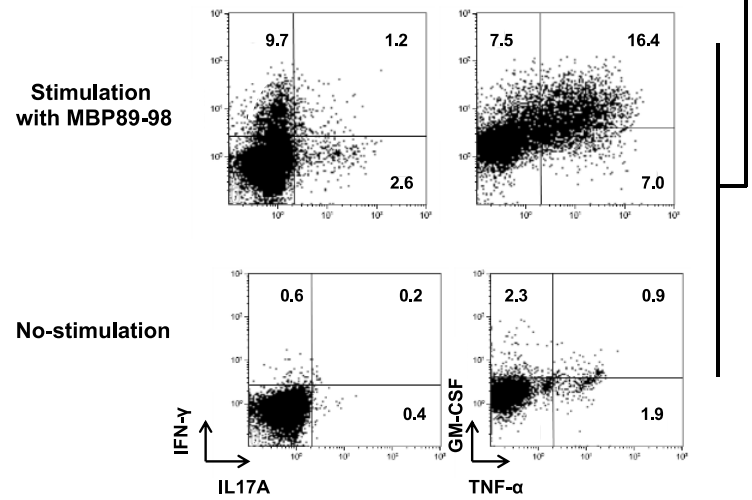

Figure 4. Induction of EAE in MBP-TCR/DR2a Tg mice upon immunization with $C$. difficile DJNS06-36 SLPA protein. (A) MBP-TCR/DR2a Tg mice $(n=10)$ were immunized with LMW-SLPA/CFA and development of EAE was examined. The combined data from two independent experiments is presented. (B) Development of Th1 and Th17 cells in EAE mice. Spinal cords isolated from EAE mice were stained with CD11b, CD45, CD4, CD3, IL-17A, and IFN- $\gamma$ mAbs. CD45 ${ }^{+}$CD11b $^{-}$CD3 ${ }^{+}$ $\mathrm{CD}^{+} \mathrm{T}$ cells were gated and examined for development of Th1 (IFN- $\left.\gamma^{+}\right)$, Th17 (IL-17A $\left.{ }^{+}\right)$, and ThGM $\left(\mathrm{GM}-\mathrm{CSF}{ }^{+}\right)$cells . 


\section{Discussion}

Microbial infections have long been suggested to be involved in triggering MS [37]. Molecular mimicry is one potential mechanism that explains how infectious agents and/or microbes might induce immune-mediated diseases such as MS [38,39]. This hypothesis proposes that self-reactive $\mathrm{T}$ and/or B cells that drive immune-mediated diseases initially encounter and become activated by bacteria or viruses possessing shared antigenic determinants, or mimotopes, with host self-antigens. $\mathrm{MBP}_{89-98}$ is one of the encephalitogenic autoantigens and MBP-specific T cells are present in healthy individuals. Although myelin-reactive $\mathrm{T}$ cells undergo central and peripheral tolerance [40], an environmental stimulus that can induce the development of myelin-specific encephalitogenic Th1 or Th17 cells could be a risk factor for MS. An early MS study showed that mimotopes of MBP are expressed in certain types of viruses, such as hepatitis B virus, which encodes an encephalitogenic epitope within the hepatitis virus B polymerase [2]. Epstein-Bar virus (EBV) is also a well-known MS-associated virus and MBP-specific T cells cross-react to EBV peptides [41,42]. Another study showed that MBP-specific antibodies purified from MS patients cross-react to EBV latent membrane protein 1 [43]. Therefore, EBV-derived MBP mimotopes may be involved in disease initiation and/or progression of MS.

Recent studies suggest that gut dysbiosis reduces intestinal microbiota species involved in the development of Foxp3 ${ }^{+}$Tregs [44]. This dysbiosis-mediated reduction in regulatory cells could increase the risk of developing MS. In addition, DCs sample luminal bacteria antigens and induce the development of Th1 and Th17 cells specific for enteric bacteria antigens [45]. Indeed, intestinal microbiota-specific memory $\mathrm{CD} 4^{+} \mathrm{T}$ cells are abundant in the peripheral blood [17]. Importantly, blood circulation of microbial protein-specific $\mathrm{T}$ cells increases upon induction of gut dysbiosis-mediated intestinal inflammation [16]. If colonization of gut bacteria expressing an MBP mimotope is elevated, an increase in blood circulating MBP mimotope-reactive T cells and MBP mimotope ${ }^{+}$DCs may increase the risk of MS. Therefore, we investigated whether MBP mimotopes are expressed in enteric bacteria. We showed here that SLPA $_{180-189}$ found in C. difficile DJNS0636 possesses an $\mathrm{MBP}_{89-98}$ mimotope. Since MBP-TCR/DR2a Tg mice express a single TCR specific for $\mathrm{MBP}_{89-98} / \mathrm{DR} 2 \mathrm{a}$, future studies are necessary to examine the frequency of $\mathrm{MBP}_{89-98}$-reactive $\mathrm{T}$ cells that can respond to DJNS06-36 SLPA $180-189$ :DR2a complexes in HLA-DR2a ${ }^{+}$individuals.

C. difficile is a well-known anaerobic bacterium that can be pathogenic in the gut, as it can cause nosocomial antibiotic-associated diarrhea and colitis in humans [46]. However, C. difficile does not always cause diarrhea and colitis. Approximately $4.0-7.6 \%$ of healthy adults actually carry $C$. difficile bacteria in their gut $[47,48]$. Since non-toxigenic strains also express SLPA, non-toxigenic $C$. difficile expressing an $\mathrm{MBP}_{89-98}$ mimotope may increase the risk of MS. SLPA is the most abundant surface protein on $C$. difficile that interacts with intestinal epithelial cells. Among C. difficile subtypes, the protein sequence of SLPA is heterogenous [49,50]. SLPA consists of low- and high-molecular-weight S-layer protein A (LMW-SLPA and HMW-SLPA, respectively) and LMW-SLPA has a heterogenous sequence [26,51]. C. difficile DJNS06-36 expresses an $\mathrm{MBP}_{89-98}$ mimotope, whereas C. difficile JND10-141 does not express the mimotope. This difference is due to heterogenicity in LMW-SLPA as shown in Figure 1B and Table 2. We further produced LMW-SLPA from C. difficile DJNS06-36 and found that LMW-SLPA expressed in C. difficile DJNS06-36 contains an $\mathrm{MBP}_{89-98}$ mimotope upon co-culture with myelin-reactive, MBP-specific T cells. Since $C$. difficile was reportedly able to colonize antibiotic treated C57BL/6 mice [52], we inoculated C. difficile DJNS06-36 into MBP-TCR/DR2a Tg mice after antibiotic treatment to evaluate their frequency of EAE development. However, these animals failed to develop EAE (data not shown). Since weight loss and intestinal inflammation were minimal in the inoculated MBP-TCR/DR2a Tg mice, the colonization of MBP-TCR/DR2a Tg mice with C. difficile DJNS06-36 may be insufficient.

Importantly, SLPAs are involved in activation of innate cells through binding to Toll-like receptor (TLR) [53,54], and TLR stimulation induces the maturation of DCs and 
subsequently induces the development of Th1 and Th17 cells [35]. Therefore, the development of SLPA-specific Th17 cells may play a role in the clearance of $C$. difficile. The SLPA-activated DCs may also differentiate into pathogenic DCs that present the $\mathrm{MBP}_{89-98}$ mimotope, and their migration into systemic circulation may contribute to the development of CNS autoimmunity. However, it is still unknown whether infection with C. difficile DJNS06-36 increases the risk of MS development in humans. Since C. difficile DJNS06-36 RTgc0636 has been rarely detected in Japan $[26,55,56]$, we further investigated the NCBI Microbial Protein Database with the SLPA mimotope and found that the SLPA mimotope is expressed in three other C. difficile strains, JND 08-232 (RTaz08232), strain 630 (RT012), and strain RIGLD-284 (RT not reported), isolated in Japan, Switzerland, and Iran, respectively $[57,58]$. Future studies are necessary to explore the association between infections caused by these $C$. difficile strains and CNS autoimmunity in HLA-DR15 ${ }^{+}$individuals.

Author Contributions: Conceptualization, K.I.; methodology, J.E.M., S.K.Y., N.I., H.K., and M.S.; formal analysis, J.E.M., S.K.Y., and K.I.; writing-original draft preparation, K.I. and J.E.M.; writingreview and editing, S.K.Y., S.D.-J., and H.K.; supervision, K.I., funding acquisition, K.I. All authors have read and agreed to the published version of the manuscript.

Funding: This study was supported in part from NJ Health Foundation (NJHF-PC 90-12).

Institutional Review Board Statement: All animal experiments were carried out in compliance with and according to the guidelines of the Guide for the Care and Use of Laboratory Animal Resources and approved by the Rutgers-Robert Wood Johnson Medical School Institutional Animal Care and Use Committee.

Data Availability Statement: Data is contained within the article and can be made further available upon request from the corresponding author.

Conflicts of Interest: The authors declare no conflict of interest.

\section{References}

1. Yadav, S.K.; Mindur, J.E.; Ito, K.; Dhib-Jalbut, S. Advances in the immunopathogenesis of multiple sclerosis. Curr. Opin. Neurol. 2015, 28, 206-219. [CrossRef]

2. Fujinami, R.S.; Oldstone, M.B. Amino acid homology between the encephalitogenic site of myelin basic protein and virus: Mechanism for autoimmunity. Science 1985, 230, 1043-1045. [CrossRef] [PubMed]

3. Gran, B.; Hemmer, B.; Vergelli, M.; McFarland, H.F.; Martin, R. Molecular mimicry and multiple sclerosis: Degenerate T-cell recognition and the induction of autoimmunity. Ann. Neurol. 1999, 45, 559-567. [CrossRef]

4. Martin, R.; Gran, B.; Zhao, Y.; Markovic-Plese, S.; Bielekova, B.; Marques, A.; Sung, M.H.; Hemmer, B.; Simon, R.; McFarland, H.F.; et al. Molecular mimicry and antigen-specific T cell responses in multiple sclerosis and chronic CNS Lyme disease. J. Autoimmun. 2001, 16, 187-192. [CrossRef] [PubMed]

5. Venigalla, S.S.K.; Premakumar, S.; Janakiraman, V. A possible role for autoimmunity through molecular mimicry in alphavirus mediated arthritis. Sci. Rep. 2020, 10, 938. [CrossRef] [PubMed]

6. Gil-Cruz, C.; Perez-Shibayama, C.; De Martin, A.; Ronchi, F.; van der Borght, K.; Niederer, R.; Onder, L.; Lutge, M.; Novkovic, M.; Nindl, V.; et al. Microbiota-derived peptide mimics drive lethal inflammatory cardiomyopathy. Science 2019, 366, 881-886. [CrossRef] [PubMed]

7. Haines, J.L.; Terwedow, H.A.; Burgess, K.; Pericak-Vance, M.A.; Rimmler, J.B.; Martin, E.R.; Oksenberg, J.R.; Lincoln, R.; Zhang, D.Y.; Banatao, D.R.; et al. Linkage of the MHC to familial multiple sclerosis suggests genetic heterogeneity. The Multiple Sclerosis Genetics Group. Hum. Mol. Genet. 1998, 7, 1229-1234. [CrossRef]

8. Miyake, S.; Kim, S.; Suda, W.; Oshima, K.; Nakamura, M.; Matsuoka, T.; Chihara, N.; Tomita, A.; Sato, W.; Kim, S.W.; et al. Dysbiosis in the Gut Microbiota of Patients with Multiple Sclerosis, with a Striking Depletion of Species Belonging to Clostridia XIVa and IV Clusters. PLoS ONE 2015, 10, e0137429. [CrossRef]

9. Jangi, S.; Gandhi, R.; Cox, L.M.; Li, N.; von Glehn, F.; Yan, R.; Patel, B.; Mazzola, M.A.; Liu, S.; Glanz, B.L.; et al. Alterations of the human gut microbiome in multiple sclerosis. Nat. Commun. 2016, 7, 12015. [CrossRef]

10. Chen, J.; Chia, N.; Kalari, K.R.; Yao, J.Z.; Novotna, M.; Soldan, M.M.; Luckey, D.H.; Marietta, E.V.; Jeraldo, P.R.; Chen, X.; et al. Multiple sclerosis patients have a distinct gut microbiota compared to healthy controls. Sci. Rep. 2016, 6, 28484. [CrossRef]

11. Cosorich, I.; Dalla-Costa, G.; Sorini, C.; Ferrarese, R.; Messina, M.J.; Dolpady, J.; Radice, E.; Mariani, A.; Testoni, P.A.; Canducci, F.; et al. High frequency of intestinal TH17 cells correlates with microbiota alterations and disease activity in multiple sclerosis. Sci. Adv. 2017, 3, e1700492. [CrossRef]

12. Atarashi, K.; Tanoue, T.; Shima, T.; Imaoka, A.; Kuwahara, T.; Momose, Y.; Cheng, G.; Yamasaki, S.; Saito, T.; Ohba, Y.; et al. Induction of colonic regulatory T cells by indigenous Clostridium species. Science 2011, 331, 337-341. [CrossRef] [PubMed] 
13. Mangalam, A.; Shahi, S.K.; Luckey, D.; Karau, M.; Marietta, E.; Luo, N.; Choung, R.S.; Ju, J.; Sompallae, R.; Gibson-Corley, K.; et al. Human Gut-Derived Commensal Bacteria Suppress CNS Inflammatory and Demyelinating Disease. Cell Rep. 2017, 20, 1269-1277. [CrossRef] [PubMed]

14. Buscarinu, M.C.; Fornasiero, A.; Romano, S.; Ferraldeschi, M.; Mechelli, R.; Renie, R.; Morena, E.; Romano, C.; Pellicciari, G.; Landi, A.C.; et al. The Contribution of Gut Barrier Changes to Multiple Sclerosis Pathophysiology. Front. Immunol. 2019, 10, 1916. [CrossRef] [PubMed]

15. Wu, H.J.; Ivanov, I.I.; Darce, J.; Hattori, K.; Shima, T.; Umesaki, Y.; Littman, D.R.; Benoist, C.; Mathis, D. Gut-residing segmented filamentous bacteria drive autoimmune arthritis via T helper 17 cells. Immunity 2010, 32, 815-827. [CrossRef] [PubMed]

16. Cook, L.; Lisko, D.J.; Wong, M.Q.; Garcia, R.V.; Himmel, M.E.; Seidman, E.G.; Bressler, B.; Levings, M.K.; Steiner, T.S. Analysis of Flagellin-Specific Adaptive Immunity Reveals Links to Dysbiosis in Patients With Inflammatory Bowel Disease. Cell. Mol. Gastroenterol. Hepatol. 2020, 9, 485-506. [CrossRef]

17. Hegazy, A.N.; West, N.R.; Stubbington, M.J.T.; Wendt, E.; Suijker, K.I.M.; Datsi, A.; This, S.; Danne, C.; Campion, S.; Duncan, S.H.; et al. Circulating and Tissue-Resident CD4(+) T Cells With Reactivity to Intestinal Microbiota Are Abundant in Healthy Individuals and Function Is Altered During Inflammation. Gastroenterology 2017, 153, 1320-1337.e16. [CrossRef]

18. Wucherpfennig, K.W.; Zhang, J.; Witek, C.; Matsui, M.; Modabber, Y.; Ota, K.; Hafler, D.A. Clonal expansion and persistence of human T cells specific for an immunodominant myelin basic protein peptide. J. Immunol. 1994, 152, 5581-5592.

19. Quandt, J.A.; Huh, J.; Baig, M.; Yao, K.; Ito, N.; Bryant, M.; Kawamura, K.; Pinilla, C.; McFarland, H.F.; Martin, R.; et al. Myelin basic protein-specific TCR/HLA-DRB5*01:01 transgenic mice support the etiologic role of DRB5*01:01 in multiple sclerosis. J. Immunol. 2012, 189, 2897-2908. [CrossRef]

20. Yadav, S.K.; Boppana, S.; Ito, N.; Mindur, J.E.; Mathay, M.T.; Patel, A.; Dhib-Jalbut, S.; Ito, K. Gut dysbiosis breaks immunological tolerance toward the central nervous system during young adulthood. Proc. Natl. Acad. Sci. USA 2017, 114, E9318-E9327. [CrossRef]

21. Guarner, F.; Malagelada, J.R. Gut flora in health and disease. Lancet 2003, 361, 512-519. [CrossRef]

22. Li, Y.; Li, H.; Martin, R.; Mariuzza, R.A. Structural basis for the binding of an immunodominant peptide from myelin basic protein in different registers by two HLA-DR2 proteins. J. Mol. Biol. 2000, 304, 177-188. [CrossRef] [PubMed]

23. Li, Y.; Huang, Y.; Lue, J.; Quandt, J.A.; Martin, R.; Mariuzza, R.A. Structure of a human autoimmune TCR bound to a myelin basic protein self-peptide and a multiple sclerosis-associated MHC class II molecule. EMBO J. 2005, 24, 2968-2979. [CrossRef] [PubMed]

24. Wang, P.; Sidney, J.; Dow, C.; Mothe, B.; Sette, A.; Peters, B. A systematic assessment of MHC class II peptide binding predictions and evaluation of a consensus approach. PLoS Comput. Biol. 2008, 4, e1000048. [CrossRef] [PubMed]

25. Wang, P.; Sidney, J.; Kim, Y.; Sette, A.; Lund, O.; Nielsen, M.; Peters, B. Peptide binding predictions for HLA DR, DP and DQ molecules. BMC Bioinform. 2010, 11, 568. [CrossRef]

26. Kato, H.; Kato, H.; Ito, Y.; Akahane, T.; Izumida, S.; Yokoyama, T.; Kaji, C.; Arakawa, Y. Typing of Clostridium difficile isolates endemic in Japan by sequencing of slpA and its application to direct typing. J. Med. Microbiol. 2010, 59, 556-562. [CrossRef]

27. Yang, Y.; Weiner, J.; Liu, Y.; Smith, A.J.; Huss, D.J.; Winger, R.; Peng, H.; Cravens, P.D.; Racke, M.K.; Lovett-Racke, A.E. T-bet is essential for encephalitogenicity of both Th1 and Th17 cells. J. Exp. Med. 2009, 206, 1549-1564. [CrossRef]

28. Vergelli, M.; Hemmer, B.; Utz, U.; Vogt, A.; Kalbus, M.; Tranquill, L.; Conlon, P.; Ling, N.; Steinman, L.; McFarland, H.F.; et al. Differential activation of human autoreactive $\mathrm{T}$ cell clones by altered peptide ligands derived from myelin basic protein peptide (87-99). Eur. J. Immunol. 1996, 26, 2624-2634. [CrossRef]

29. Vogt, A.B.; Kropshofer, H.; Kalbacher, H.; Kalbus, M.; Rammensee, H.G.; Coligan, J.E.; Martin, R. Ligand motifs of HLADRB5*0101 and DRB1*1501 molecules delineated from self-peptides. J. Immunol. 1994, 153, 1665-1673.

30. Waligora, A.J.; Hennequin, C.; Mullany, P.; Bourlioux, P.; Collignon, A.; Karjalainen, T. Characterization of a cell surface protein of Clostridium difficile with adhesive properties. Infect. Immun. 2001, 69, 2144-2153. [CrossRef]

31. Calabi, E.; Calabi, F.; Phillips, A.D.; Fairweather, N.F. Binding of Clostridium difficile surface layer proteins to gastrointestinal tissues. Infect. Immun 2002, 70, 5770-5778. [CrossRef]

32. Merrigan, M.M.; Venugopal, A.; Roxas, J.L.; Anwar, F.; Mallozzi, M.J.; Roxas, B.A.; Gerding, D.N.; Viswanathan, V.K.; Vedantam, G. Surface-layer protein A (SlpA) is a major contributor to host-cell adherence of Clostridium difficile. PLoS ONE 2013, 8, e78404. [CrossRef] [PubMed]

33. Drudy, D.; Calabi, E.; Kyne, L.; Sougioultzis, S.; Kelly, E.; Fairweather, N.; Kelly, C.P. Human antibody response to surface layer proteins in Clostridium difficile infection. FEMS Immunol. Med. Microbiol. 2004, 41, 237-242. [CrossRef] [PubMed]

34. Ausiello, C.M.; Cerquetti, M.; Fedele, G.; Spensieri, F.; Palazzo, R.; Nasso, M.; Frezza, S.; Mastrantonio, P. Surface layer proteins from Clostridium difficile induce inflammatory and regulatory cytokines in human monocytes and dendritic cells. Microbes Infect. 2006, 8, 2640-2646. [CrossRef]

35. Ryan, A.; Lynch, M.; Smith, S.M.; Amu, S.; Nel, H.J.; McCoy, C.E.; Dowling, J.K.; Draper, E.; O’Reilly, V.; McCarthy, C.; et al. A role for TLR4 in Clostridium difficile infection and the recognition of surface layer proteins. PLOS Pathog. 2011, 7, e1002076. [CrossRef] [PubMed]

36. Bruxelle, J.F.; Mizrahi, A.; Hoys, S.; Collignon, A.; Janoir, C.; Pechine, S. Immunogenic properties of the surface layer precursor of Clostridium difficile and vaccination assays in animal models. Anaerobe 2016, 37, 78-84. [CrossRef]

37. Cossu, D.; Yokoyama, K.; Hattori, N. Bacteria-Host Interactions in Multiple Sclerosis. Front. Microbiol. 2018, 9, 2966. [CrossRef] 
38. Oldstone, M.B. Molecular mimicry, microbial infection, and autoimmune disease: Evolution of the concept. Curr. Top. Microbiol. Immunol. 2005, 296, 1-17.

39. Chastain, E.M.; Miller, S.D. Molecular mimicry as an inducing trigger for CNS autoimmune demyelinating disease. Immunol. Rev. 2012, 245, 227-238. [CrossRef]

40. Goverman, J.M. Immune tolerance in multiple sclerosis. Immunol. Rev. 2011, 241, 228-240. [CrossRef] [PubMed]

41. Wucherpfennig, K.W.; Strominger, J.L. Molecular mimicry in T cell-mediated autoimmunity: Viral peptides activate human T cell clones specific for myelin basic protein. Cell 1995, 80, 695-705. [CrossRef]

42. Lang, H.L.; Jacobsen, H.; Ikemizu, S.; Andersson, C.; Harlos, K.; Madsen, L.; Hjorth, P.; Sondergaard, L.; Svejgaard, A.; Wucherpfennig, K.; et al. A functional and structural basis for TCR cross-reactivity in multiple sclerosis. Nat. Immunol. 2002, 3 , 940-943. [CrossRef]

43. Lomakin, Y.; Arapidi, G.P.; Chernov, A.; Ziganshin, R.; Tcyganov, E.; Lyadova, I.; Butenko, I.O.; Osetrova, M.; Ponomarenko, N.; Telegin, G.; et al. Exposure to the Epstein-Barr Viral Antigen Latent Membrane Protein 1 Induces Myelin-Reactive Antibodies In Vivo. Front. Immunol. 2017, 8, 777. [CrossRef] [PubMed]

44. Noto, D.; Miyake, S. Gut dysbiosis and multiple sclerosis. Clin. Immunol. 2020, 108380. [CrossRef] [PubMed]

45. Farache, J.; Koren, I.; Milo, I.; Gurevich, I.; Kim, K.W.; Zigmond, E.; Furtado, G.C.; Lira, S.A.; Shakhar, G. Luminal bacteria recruit CD103+ dendritic cells into the intestinal epithelium to sample bacterial antigens for presentation. Immunity 2013, 38, 581-595. [CrossRef] [PubMed]

46. Madan, R.; Petri, W.A., Jr. Immune responses to Clostridium difficile infection. Trends Mol. Med. 2012, 18, 658-666. [CrossRef] [PubMed]

47. Kato, H.; Kita, H.; Karasawa, T.; Maegawa, T.; Koino, Y.; Takakuwa, H.; Saikai, T.; Kobayashi, K.; Yamagishi, T.; Nakamura, S. Colonisation and transmission of Clostridium difficile in healthy individuals examined by PCR ribotyping and pulsed-field gel electrophoresis. J. Med. Microbiol. 2001, 50, 720-727. [CrossRef]

48. Miyajima, F.; Roberts, P.; Swale, A.; Price, V.; Jones, M.; Horan, M.; Beeching, N.; Brazier, J.; Parry, C.; Pendleton, N.; et al. Characterisation and carriage ratio of Clostridium difficile strains isolated from a community-dwelling elderly population in the United Kingdom. PLoS ONE 2011, 6, e22804. [CrossRef]

49. Calabi, E.; Fairweather, N. Patterns of sequence conservation in the S-Layer proteins and related sequences in Clostridium difficile. J. Bacteriol. 2002, 184, 3886-3897. [CrossRef]

50. Eidhin, D.N.; Ryan, A.W.; Doyle, R.M.; Walsh, J.B.; Kelleher, D. Sequence and phylogenetic analysis of the gene for surface layer protein, slpA, from 14 PCR ribotypes of Clostridium difficile. J. Med. Microbiol. 2006, 55, 69-83. [CrossRef]

51. Bradshaw, W.J.; Roberts, A.K.; Shone, C.C.; Acharya, K.R. The structure of the S-layer of Clostridium difficile. J. Cell Commun. Signal. 2018, 12, 319-331. [CrossRef] [PubMed]

52. Chen, X.; Katchar, K.; Goldsmith, J.D.; Nanthakumar, N.; Cheknis, A.; Gerding, D.N.; Kelly, C.P. A mouse model of Clostridium difficile-associated disease. Gastroenterology 2008, 135, 1984-1992. [CrossRef] [PubMed]

53. Taverniti, V.; Stuknyte, M.; Minuzzo, M.; Arioli, S.; De Noni, I.; Scabiosi, C.; Cordova, Z.M.; Junttila, I.; Hamalainen, S.; Turpeinen, H.; et al. S-layer protein mediates the stimulatory effect of Lactobacillus helveticus MIMLh5 on innate immunity. Appl. Environ. Microbiol. 2013, 79, 1221-1231. [CrossRef] [PubMed]

54. Mursalin, M.H.; Coburn, P.S.; Livingston, E.; Miller, F.C.; Astley, R.; Flores-Mireles, A.L.; Callegan, M.C. Bacillus S-Layer-Mediated Innate Interactions During Endophthalmitis. Front. Immunol. 2020, 11, 215. [CrossRef] [PubMed]

55. Senoh, M.; Kato, H.; Fukuda, T.; Niikawa, A.; Hori, Y.; Hagiya, H.; Ito, Y.; Miki, H.; Abe, Y.; Furuta, K.; et al. Predominance of PCR-ribotypes, 018 (smz) and 369 (trf) of Clostridium difficile in Japan: A potential relationship with other global circulating strains? J. Med. Microbiol. 2015, 64, 1226-1236. [CrossRef] [PubMed]

56. Kato, H.; Senoh, M.; Honda, H.; Fukuda, T.; Tagashira, Y.; Horiuchi, H.; Chiba, H.; Suzuki, D.; Hosokawa, N.; Kitazono, H.; et al. Clostridioides (Clostridium) difficile infection burden in Japan: A multicenter prospective study. Anaerobe 2019, 60, 102011. [CrossRef]

57. Sebaihia, M.; Wren, B.W.; Mullany, P.; Fairweather, N.F.; Minton, N.; Stabler, R.; Thomson, N.R.; Roberts, A.P.; Cerdeno-Tarraga, A.M.; Wang, H.; et al. The multidrug-resistant human pathogen Clostridium difficile has a highly mobile, mosaic genome. Nat. Genet. 2006, 38, 779-786. [CrossRef]

58. Wust, J.; Sullivan, N.M.; Hardegger, U.; Wilkins, T.D. Investigation of an outbreak of antibiotic-associated colitis by various typing methods. J. Clin. Microbiol. 1982, 16, 1096-1101. [CrossRef] 